\title{
Ontogenetic stages in the long bone histology of sauropod dinosaurs
}

\author{
Nicole Klein and Martin Sander
}

\begin{abstract}
Long bones (femora, humeri) are the most abundant remains of sauropod dinosaurs. Their length is a good proxy for body length and body mass, and their histology is informative about ontogenetic age. Here we provide a comparative assessment of histologic changes in growth series of several sauropod taxa, including diplodocids (Apatosaurus, Diplodocus, indeterminate Diplodocinae from the Tendaguru Beds and from the Morrison Formation), basal macronarians ( $\mathrm{Ca}$ marasaurus, Brachiosaurus, Europasaurus), and titanosaurs (Phuwiangosaurus, Ampelosaurus). A total of 167 long bones, mainly humeri and femora, and $18 \mathrm{limb}$ girdle bones were sampled. Sampling was performed by core drilling at prescribed locations at midshaft, and 13 histologic ontogenetic stages (HOS stages) were recognized. Because growth of all sauropod long bones is quite uniform, with laminar fibrolamellar bone being the dominant tissue, HOS stages could be recognized across taxa, although with minor differences. Histologic ontogenetic stages generally correlate closely with body size and thus provide a means to resolve important issue like the ontogenetic status of questionable specimens. We hypothesize that sexual maturity was attained at HOS- 8 , well before maximum size was attained, but we did not find sexually differentiated growth trajectories subsequent to HOS-8. On the basis of HOS stages, we detected two morphotypes in the Camarasaurus sample, a small one (type 1) and a larger one (type 2), presumably representing different species or sexual dimorphism.
\end{abstract}

Nicole Klein and Martin Sander. Institut für Paläontologie, Universität Bonn, Nußallee 8, D-53115 Bonn, Germany.E-mail:nklein@uni-bonn.de,martin.sander@uni-bonn.de

Accepted: 25 October 2007

\section{Introduction}

In extant wild vertebrates, age determination is possible by mark-release-recapture studies. Additionally morphology and size of an individual can be indicators of age. Obviously, the mark-release-recapture method is not applicable to extinct animals, and also morphology and size as age indicators are difficult to use in fossils. Often it is not clear, because of the incompleteness of the fossil record, whether differences in size and morphology reflect ontogenetic and allometric or taxonomic differences. However, because of ontogenetic changes in growth rate and bone tissue type, long bone histology can also record the ontogenetic history of an individual.

Since the last decade, histology of fossil bone has become a frequently used and productive method for studying the ontogeny and life history of extinct amniotes and especially dinosaurs. Thus, long bone histology provides a unique approach to gathering information about the biology and life history of dinosaurs.

Early ontogenetic stages have been described on the basis of morphology and size for other dinosaurs, but juveniles are rather rare for sauropods (Gilmore 1925; Carpenter and McIntosh 1994; Martin 1994; Chiappe and Coria 2001; Lehmann and Coulson 2002; Wilhite 2003; Bonnan 2004; Foster 2005; Ikejiri et al. 2005; Tidwell and Wilhite 2005; Sander et al. 2006; Schwarz et al. 2007).

Histologic determination of the ontogenetic status in sauropods has the potential to resolve the question of whether a small sauropod specimen is a juvenile or a dwarf form. For example, the dwarf status of the diminutive basal macronarian Europasaurus holgeri (Sander et al. 2006) was proven histologically, as well as the juvenile status of a small diplodocid specimen from the Morrison Formation (Schwarz et al. 2007). How difficult dwarfing is to prove without histology is illustrated by the titanosaurid Magyarosaurus from the Late Cretaceous of Romania; although this is the classical example of insular dwarfing in dinosaurs (Nopcsa 1914; Jianu and Weishampel 1999), its dwarf status has recently been questioned (Le Loeuff 2005b). Additionally, taxonomic diversity can be detected by bone histology in a morphologically homogeneous 
sample (e.g., Camarasaurus, Ampelosaurus, Phuwiangosaurus, this study).

Studies on ontogenetic stages using bone histology have been done before in dinosaurs (Varricchio 1993; Chinsamy 1994; Curry 1999; Erickson and Tumanova 2000; Horner et al. 2000; Sander 2000; Horner and Padian 2004; Chinsamy-Turan 2005; Erickson 2005). However, because of biological and taphonomic filters, juveniles and adults of a single species are rarely preserved together at the same locality. Moreover, because juveniles rarely show morphological autapomorphies, for most species it is still difficult to assign these specimens to the corresponding adult specimens even when they are found together (e.g., Chiappe et al. 2005; Schwarz et al. 2007). Additionally, most of the bone histological studies in the past have dealt only with two ontogenetic stages, the late stage of active growth, indicated in most dinosaurs by laminar fibrolamellar bone, and the cessation of growth (Varricchio 1993; Chinsamy 1994; Curry 1999; Erickson and Tumanova 2000; Horner et al. 2000; Sander 2000; Horner et al. 2001; Horner and Padian 2004; Chinsamy-Turan 2005; Erickson 2005). In fact, it is becoming common practice in the description of new dinosaur taxa to use bone histology to ascertain the ontogenetic stage of the type material (Sander et al. 2006; Erickson et al. 2006; Xu et al. 2007). The cessation of growth is indicated by avascular lamellar-zonal bone in the outermost cortex, the so-called external fundamental system (EFS) (Cormack 1987) or outer circumferential lamella (OCL) (Chinsamy-Turan 2005). Mainly because dinosaurs of early ontogenetic stages are poorly represented in the fossil record and difficult to identify, only a few studies have dealt with earlier ontogenetic stages or a range of ontogenetic stages on the basis of bone histology (Varricchio 1993; Curry 1999; Erickson and Tumanova 2000; Horner et al. 2000; Chinsamy-Turan 2005; Erickson 2005).

One of the best and, concerning the ontogeny, most complete studies is that of the hadrosaurid Maiasaura by Horner et al. (2000), who studied various long bones and other bones. They described six gradational growth stages in the principally fibrolamellar primary bone tissue: early and late nestling, early and late juvenile, subadult, and adult. These histological growth stages are also well supported by the relative sizes of the bones (Horner et al. 2000: Table 1).

Erickson and Tumanova (2000) studied a growth series from juveniles to adults of the ceratopsian Psittacosaurus monogoliensis. They recognized seven different growth stages (growth stages $A-G)$, which were defined by the number of lines of arrested growth and the femur size (Erickson and Tumanova 2000: Table 2).

Curry (1999) studied an ontogenetic series of Apatosaurus on the basis of the histology of radii, ulnae, and scapulae. She distinguished four different osteogenic phases: a juvenile stage $(<73 \%$ of adult size), which is subdivided into an early $(<34 \%$ of adult size) and a late $(<73 \%$ of adult size) juvenile stage, a subadult stage $(91 \%$ of adult size), and an adult, fully grown stage. Sander $(1999,2000)$ independently recognized essentially the same four stages in the sauropod taxa from the Late Jurassic Tendaguru Beds, interpreting them as hatchling, juvenile, adult, and fully grown ("senile") on the basis of the hypothesis that sexual maturity occurred well before maximum size. Curry (1999), on the other hand, had hypothesized that only the fully grown individual in her sample was a sexually mature adult.

It is the purpose of this paper to describe in detail ontogenetic changes in the histology of sauropod long bones based on a large and taxonomically diverse sample of mainly neosauropods, greatly expanding on the study by Sander (2000). We erect 13 histologic ontogenetic stages (HOS stages) that serve to compare life histories of sauropods. This approach is particularly useful in the virtual absence of a growth mark record in sauropods, which makes quantitative life-history comparisons impossible. The terminology largely follows Francillon-Vieillot et al. (1990).

\section{Museum Abbreviations}

BYU Museum of Earth Sciences, Brigham Young University, Provo, Utah, USA

CM Carnegie Museum of Natural History, Pennsylvania, USA

DFMMh/FV Dinosaurier-Freilichtmuseum Münchehagen/Verein zur Förderung der 


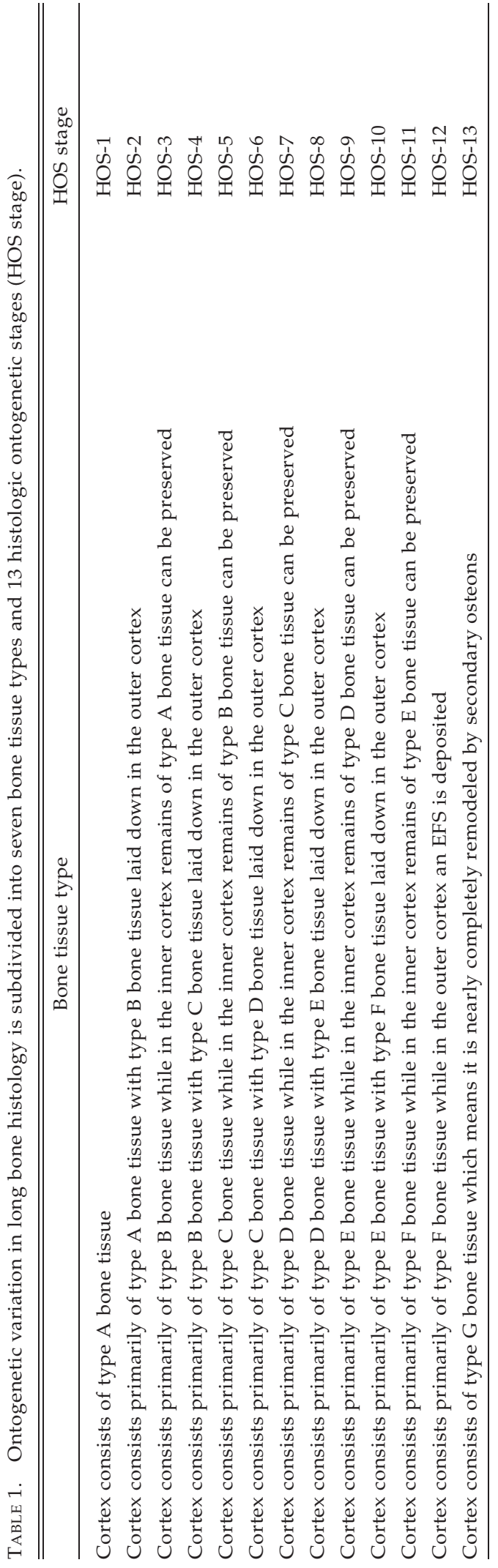

Niedersächsischen Paläontologie (e.V.), Germany

IPB Institut für Paläontologie, Universität Bonn, Germany

LMC Local Museum Cruzy, Cruzy, France

MDE Musée des Dinosaures, Esperaza, France

MfN Museum für Naturkunde der Humboldt-Universität zu Berlin, Berlin, Germany

OMNH Oklahoma Museum of Natural History, Norman, Oklahoma, U.S.A.

PC.DMR Palaeontological collection, Department of Mineral Resources, Khon Kaen, Kalasin, Thailand

SMA Sauriermuseum Aathal, Aathal, Canton Zürich, Switzerland

\section{Material}

Specimens Studied.-The histological data base consists of 185 samples (167 long bone samples, 18 girdle bone samples) derived from over 12 well-known sauropod taxa (see Appendix online at http://dx.doi.org/10.1666/ 07017.s1). The material comes from different localities in North America (Late Jurassic Morrison Formation), East Africa (Late Jurassic Tendaguru Beds), Europe (Late Jurassic of the Lower Saxony Basin, northern Germany; Late Cretaceous of the Marnes Rouges Inférieures Formation and Marnes de la Maurine member, department of Aude, France), and northern Thailand (Late Triassic Nam Phong Formation; Early Cretaceous Sao Khua Formation). It was obtained during several trips to different collections over the last decade. Identification of the material is based on the collections labels and, in some cases, on more current published information (see Appendix). Species assignment based on long bones is difficult in sauropods, and many isolated long bones were identified only to genus or subfamily level. This is why we discuss the material largely at this level. Figure 1 gives an overview of the phylogeny of the studied sauropods. All samples were obtained and studied first hand, except for the small Apatosaurus tibia OMNH 1285, which was sampled and processed by Andrew Lee (University of California, Berkeley), who kindly provided a high-resolution photomicrograph for this study. 


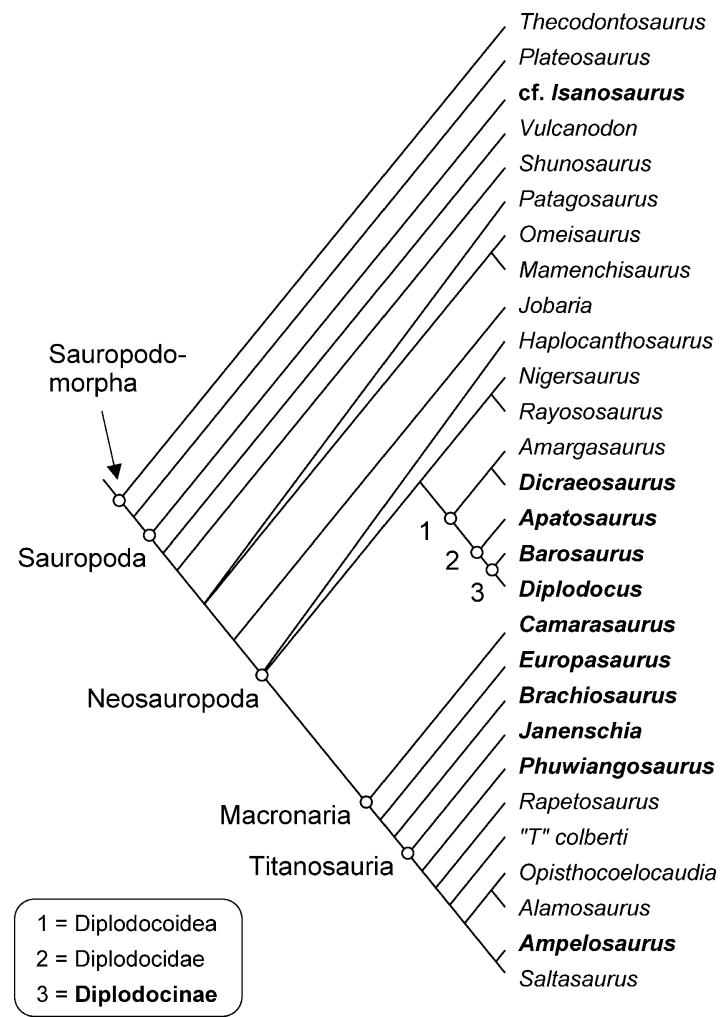

FIGURE 1. Sauropod relationships after Wilson (2002). The genera and the subfamily printed in bold were sampled for this study.

\section{Methods}

Sampling by Coring and Cross-Sectioning.Because of their relatively simple appositional growth and for a better comparison, we studied long bones predominately. The material was usually sampled by core drilling with a diamond drill bit at a standardized sampling location in the midshaft region of the bones (Sander 1999, 2000; Klein and Sander 2007). Additionally, cross-sections of the entire midshaft were taken in Isanosaurus, Europasaurus, and Ampelosaurus. The midshaft region of the long bones equals the neutral growth region, which contains the most complete growth record. If at all possible, the cores were drilled on the anterior side of the middle of the femur shafts and on the posterior side of the middle of the humerus shafts. It is crucial that core samples are taken from these standardized locations because otherwise comparability is compromised. However, in a few specimens, the bone surface was damaged at the prescribed location or the bone was reconstructed in plaster, necessitating sampling at a different location in the midshaft region. We drilled completely through some limb girdle bones, thus sampling the medial and the lateral cortex.

The cores as well as the cross-sections were processed into polished thin sections by standard petrographic methods. For more details see Sander $(1999,2000)$ and Klein and Sander (2007).

Methods of Histological and Skeletochronological Study.-Thin sections were photographed with a digital camera (Nikon D1) using a bellows, resulting in a field of view of about $3 \mathrm{~cm}$. Images of sections that were larger than this were created from two or three exposures with Photoshop computer software. To observe the histology in greater detail, all thin sections were examined by standard light microscopic techniques (normal transmitted light, polarized light) with a Leica DMLP compound microscope $(16 \times$ to $400 \times$ magnification). Polished sections were studied in incident light in dark-field and bright-field illumination also with the Leica DMLP compound microscope and with a binocular microscope (Sander 2000).

\section{Ontogeny and Changes in Bone Histology}

General Ontogenetic Changes in Long Bone Histology.-All sauropod long bones that we studied grew fairly uniformly, laying down laminar fibrolamellar bone tissue (FBL) in their cortex. Differences in primary bone tissue types mainly concern the organization of the vascular system, the degree of vascularization, and the presence and degree of development of primary osteons (i.e., the amount of lamellar bone deposited centripetally in the vascular canals). In cortical bone, vascular density is closely linked with bone apposition rate; i.e., less vascularization means a lower apposition rate (Amprino 1947; Chinsamy 1993; Curry 1999; Erickson and Tumanova 2000; Horner et al. 2000; Erickson 2005). This correlation can be applied to qualitative studies of growth rate where midshaft bone apposition rate is used as a proxy for the growth rate of the entire animal. Vascularization, and therefore growth rate, decreases in general with increasing age. This was noted in many 
previous bone histological studies (Chinsamy 1993; Curry 1999; Erickson and Tumanova 2000; Horner et al. 2000; Chinsamy-Turan 2005; summarized in Erickson 2005). This observation is also made in the current sauropod sample, but the extensive database from very small to very large individuals allows a refinement of this general observation.

Initial deposition of FBL is so fast that the vascular canals are large and only later are centripetally infilled by lamellar bone (Chinsamy-Turan 2005) forming primary osteons. We used the degree of this infilling for our ontogenetic division of bone tissue types. However, it should be noted that differences in development of the primary osteons among different bone tissue types do not represent completeness of infilling as the bone is deposited by the periosteum but rather varying degrees of final development, after periosteal bone deposition has ceased. In fact, many specimens show growing laminar fibrolamellar bone in the outermost three to five laminae where the gradual infilling of the primary osteons can be observed in addition to the ontogenetic sequence of development of the primary osteons deeper in the cortex.

Remodeling of bone means the replacement of primary bone by bone resorption and subsequent deposition of secondary bone. In contrast to some other dinosaurs, sauropods often show well-developed dense secondary osteons (Sander 2000; Chinsamy-Turan 2005: p. 84 ), even several generations of secondary osteons can be deposited in a single sample (= Haversian bone). In our study we found a close correlation between the histologic ontogenetic stage of the primary bone tissue and the number of secondary osteons. With increasing size and therefore also age, the number and density of secondary osteons increases, too. Thus, we included the degree of remodeling of the cortical bone in the characterization of the HOS stages.

The primary cortex is usually not stratified by growth marks in sauropods. Only very few specimens of various taxa develop growth marks in their middle and outer cortex, mainly lines of arrested growth (Sander 2000; Sander and Tückmantel 2003). The only known exception is the dwarf sauropod Europasaurus (Sander et al. 2006), which combines fibrolamellar bone with regularly spaced lines of arrested growth. However, the development of growth marks or an EFS is also an important indicator of ontogenetic age, as was documented in several previous studies (Chinsamy 1993; Varricchio 1993; Curry 1999; Erickson and Tumanova 2000; Horner et al. 2000; Chinsamy-Turan 2005; Erickson 2005).

Using changes in laminar fibrolamellar bone tissue and in intensity of remodeling by secondary osteons (number and density), we were able to differentiate seven bone tissue types that correspond to 13 HOS stages. The number of HOS stages is greater than that of the described bone tissue types because the transitions between the ontogenetic bone tissue types are always gradual, resulting in transitional stages where one or more bone tissue types are preserved in a single specimen. The HOS stages include these gradual transitions and thus allow a more precise description of the ontogenetic status of an individual than do ontogenetic bone tissue types alone.

Ontogenetic Bone Tissue Types in Long Bones. Horner et al. (2000: Fig. 2A) and Horner et al. (2001) described and figured embryonic bone tissue of embryos of Maiasaura and of some recent archosaurs. The embryonic stage is not preserved in the current sauropod sample but it is likely that sauropod embryonic bone looked similar to that in Maiasaura. From this and because of the non-laminar organization of the subsequent bone tissue type (type B) it is quite certain that the vascularization of the bone tissue laid down earliest in sauropods, designated here as type $\mathrm{A}$, did not have a laminar organization. Type B bone tissue is fibrolamellar bone that is dominated by woven or fibrous bone. The vascularization is not laminar but mainly longitudinal, and the density of the vascular canals is very high. The vascular canals are large and essentially circular in cross-section (Fig. 2A,B), but with an irregular margin, similar to small erosion cavities of the remodeling zone. However, the small erosion cavities are easily distinguished from primary vascular canals of type $B$ bone tissue by their resorption margins (Fig. 2O). Type B bone tissue normally has no true primary osteons developed, and only a thin sheath of la- 





mellar bone lines the vascular canals, indicating that primary osteon formation has started. No secondary osteons or growth marks are developed in type B bone tissue. If preserved at all, type B bone tissue occurs in our sample only in interstitial areas between the erosion cavities of the remodeling zone. It grades in all specimens into laminar type $C$ bone tissue. Type $\mathrm{B}$ bone tissue is shown in Figure 3A.

Type $\mathrm{C}$ bone tissue (Fig. $3 \mathrm{~A}-\mathrm{C}$ ) consists of a primarily laminar fibrolamellar bone with a still very high vascular canal density. Type $C$ bone tissue usually also starts with longitudinal vascular canals that later grade into vascular canals with a more circumferential organization. However, longitudinal vascular canals in type $\mathrm{C}$ bone tissue are easy to distinguish from those in type B by a more regularly round margin compared to the irregular longitudinal vascular canals in type B bone tissue (Fig. 2C). With increasing age, the vascularization gradually acquires a completely laminar organization, and simultaneously the formation of true primary osteons starts, indicated by a more distinct lining of the vascular canals by lamellar bone (Fig. 2E,F). A few specimens (e.g., Apatosaurus tibia OMNH 1285; Phuwiangosaurus femur PW 5 A-1) have type $\mathrm{C}$ bone tissue with radial vascularization (Fig. 2D), at least locally. No secondary osteons or growth marks are developed in type C bone tissue.

The transition from type $\mathrm{C}$ to type $\mathrm{D}$ bone tissue also is gradual and not abrupt. The change is again indicated by the increase in lamellar bone in the primary osteons (Fig. $2 \mathrm{G}-\mathrm{I})$, and the vascular canals in type D bone tissue have a thick lining of lamellar bone. However, vascularization is still high in type $D$ : the vascular canals are large, but smaller than in type $C$ bone tissue. Vascularization is primarily laminar, but a few areas have vermiform or more reticular organization. In type $\mathrm{D}$ bone tissue, the formation of secondary osteons starts. Thus, incompletely filled ("young") large secondary osteons (Currey 2002) develop mainly between larger erosion cavities of the remodeling zone and are closely associated with the medullary cavity (Fig. $2 \mathrm{O})$. Growth marks are rather rare in this tissue type. Type $\mathrm{D}$ bone tissue type is figured in Figure 3B,C.

Type E bone tissue (Fig. 3C,D) represents a still relatively fast growing tissue. The transition from type $\mathrm{D}$ to type $\mathrm{E}$ bone tissue again is gradual. Both types, in fact, differ only in organization and degree of vascular density. The vascular spaces in type $\mathrm{E}$ bone tissue are still present but smaller than in type $D$ be-

$\leftarrow$

FIGURE 2. A-P, Ontogenetic bone tissue types in the long bone cortex of sauropod dinosaurs. All photomicrographs were taken in normal transmitted light unless noted otherwise. A, Type B bone tissue in Phuwiangosaurus PC.DMR PW4-6 (femur fragment of unknown bone length). B, Detail of type B bone tissue in Apatosaurus OMNH 1279 (femur, $34.0 \mathrm{~cm}$ ). Note the irregular arrangement of the vascular canals and their high density. C, Type C bone tissue in Apatosaurus OMNH 1278 (humerus, $25.8 \mathrm{~cm}$ ) with longitudinal and circular vascular canals. Note the increasing laminar organization of the tissue type but the still wide-open vascular canals. D, Radial to reticular vascular organization in type C bone tissue in Phuwiangosaurus PC.DMR K16-33 (left femur, 39.0 cm). E, F, Detail of vascular canals in type $\mathrm{C}$ bone tissue in a diplodocid from the Tendaguru Beds (MfN NW4, femur $135.0 \mathrm{~cm}$ ). The formation of the primary osteons has started, as can be seen in polarized light. E, Normal transmitted light, F, Polarized light. G, Type D bone tissue in Apatosaurus (CM 21715, humerus $79.2 \mathrm{~cm}$ ). Note the laminar organization of this tissue. Polarized light. H, I, Detail of vascular canals in type D bone tissue in a diplodocid from the Tendaguru Beds (MfN NW4, femur $135.0 \mathrm{~cm}$ ). The formation of the primary osteons has continued but the vascular canals are still fairly large. H, Normal transmitted light, I, Polarized light. J, Type E bone tissue in a diplodocid from the Howe Ranch locality (SMA 647-87-1, femur $120.0 \mathrm{~cm}$ ). Note the narrow vascular canals and the strongly laminar organization. $\mathrm{K}$, Type E bone tissue in a diplodocid from the Howe Ranch locality (SMA 647-87-1, femur 120.0 cm) under polarized light. L, Detail of a primary osteon in type E bone tissue in Apatosaurus (BYU 601-17328, femur 158.0 cm). Polarized light. M, Primary osteon in type F bone tissue in Apatosaurus (BYU 601-17328, femur 158.0 cm). Note the increasing amount of lamellar bone within the fibrolamellar complex. Polarized light. N, An EFS deposited in the outer cortex of Apatosaurus (SMA M4/10-1, femur $144.0 \mathrm{~cm}$ ). Note the closely spaced growth lines and the nearly avascular bone between the outermost growth lines. Polarized light. O, Young and large secondary osteons in the remodeling zone of a diplodocid from the Tendaguru Beds (MfN XI a7, humerus $80.5 \mathrm{~cm}$ ). Polarized light. P, Dense secondary osteons in the cortex of Ampelosaurus (LMC3 602 humerus fragment of unknown bone length). Polarized light. Q, Tissue reminiscent of type B or type C bone tissue in a small Apatosaurus scapula (OMNH 1300, $35.5 \mathrm{~cm})$. R, Opposite bone side with much more mature bone tissue in the same Apatosaurus scapula (OMNH 1300, $35.5 \mathrm{~cm})$. Note the irregular vascularization. 

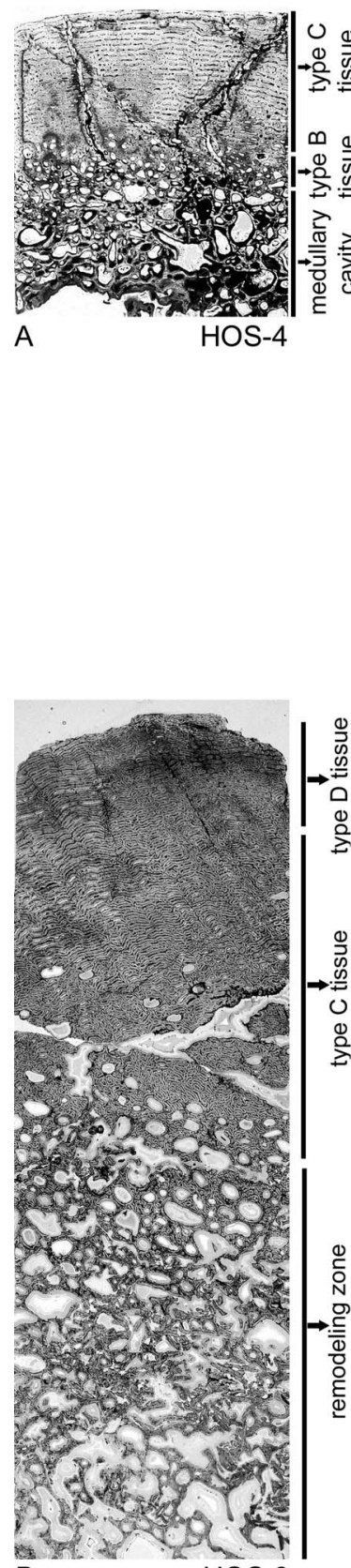

B
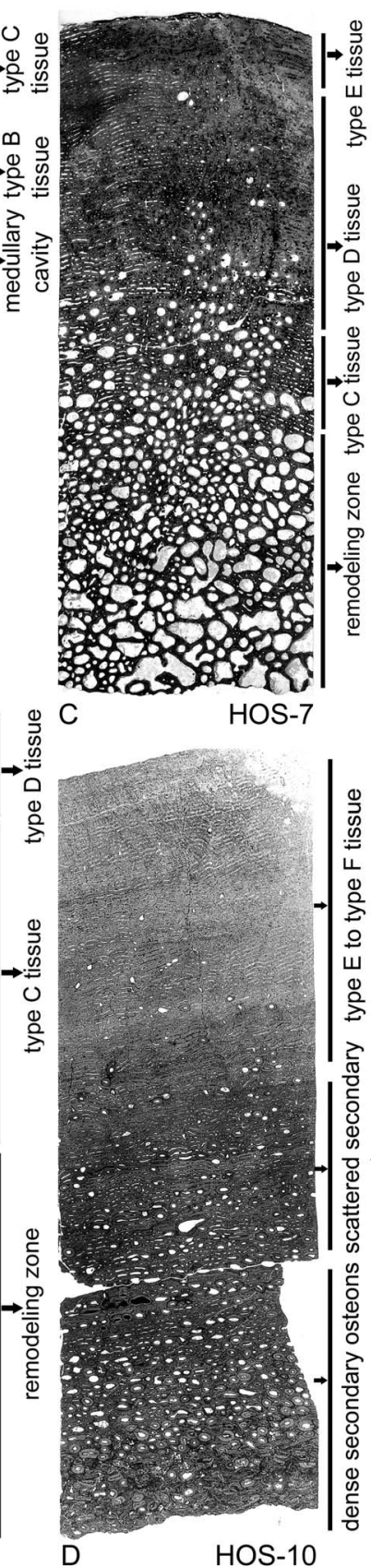
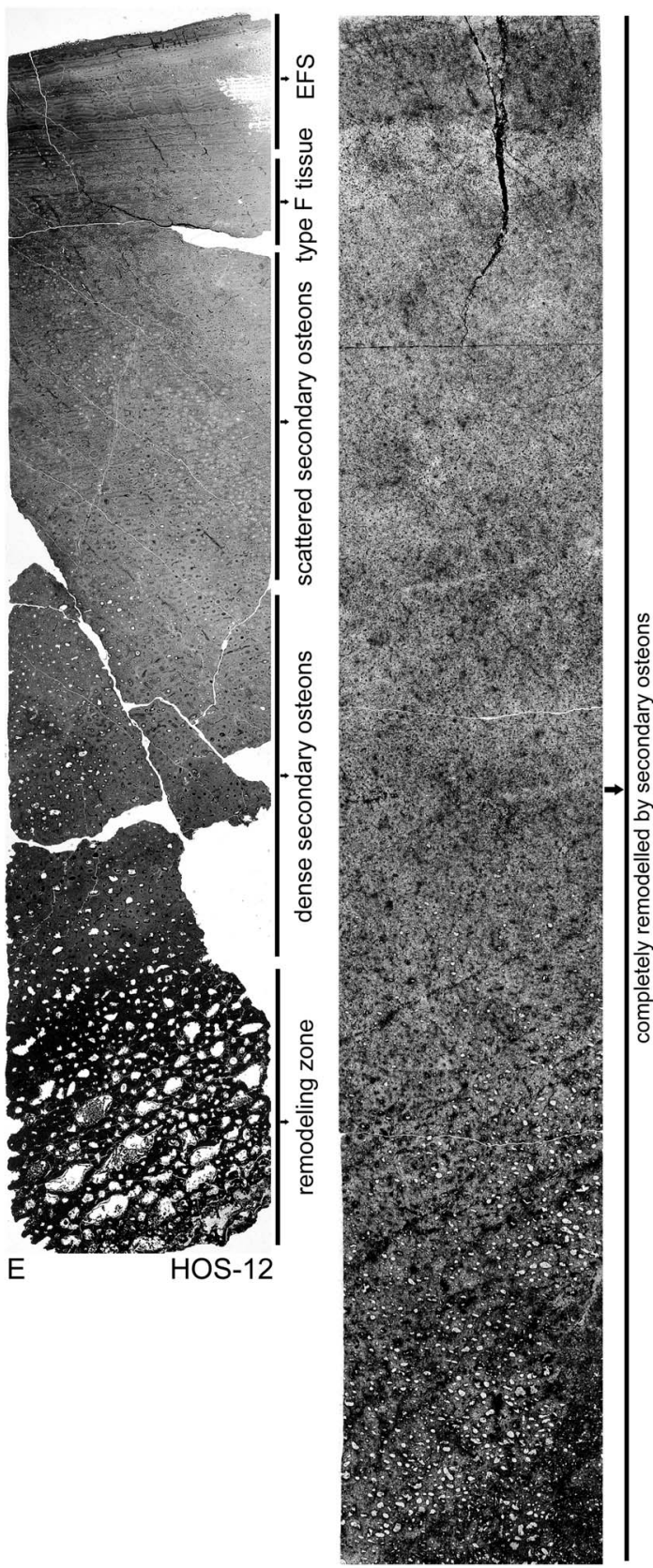

HOS- 13

FIgURE 3. A growth series of Apatosaurus specimens reaching from stage HOS 4 to HOS 13. A, Type B and type C bone tissue in humerus OMNH $1278(25.8 \mathrm{~cm})$. B, Type C and type D bone tissues in humerus CM $21715(79.2 \mathrm{~cm})$. C, Type C, D, E bone tissues in humerus BYU $681-4749(88.0 \mathrm{~cm})$. Note absence of any growth marks. D, Type E bone tissue in femur SMA $0014(164.0 \mathrm{~cm})$. Note the faint growth cycles and the appearance of secondary osteons. E, Type F bone tissue with LAGs, finally resulting in an EFS in femur BYU 601-17328 (158.0 cm). F, Completely remodeled cortex in femur OMNH $01991(180.0 \mathrm{~cm})$. 
cause the thickness of the layer of lamellar bone lining the vascular canals increases, resulting in very distinctive primary osteons (Fig. 2J-L). The secondary osteons between the erosion cavities in the inner cortex are more densely spaced (Fig. 3D) in type E bone tissue. Additionally, the spread of secondary osteons into the primary cortex has started by now, resulting in scattered secondary osteons that may extend in some specimens up to the middle of the primary cortex. Growth marks may occur, but they remain rare and are not typical for type E bone tissue.

Type F bone tissue (Fig. 3E) is characterized by a clear decrease in vascularization, finally resulting in a near complete infilling of the primary vascular canals by lamellar bone. Lines of arrested growth (LAGs) may occur in this bone tissue type. In some specimens a change from fibrolamellar to lamellar-zonal bone and the deposition of an EFS (Fig. 2N) are initiated. The EFS indicates that a growth plateau has been reached. The vascular canals of primary osteons are more or less completely filled by lamellar bone tissue (Fig. 2M). Remodeling by secondary osteons has increased significantly, and dense secondary osteons are deposited at least up to the middle to inner two-thirds of the primary cortex (Fig. 3E). In type $\mathrm{F}$ bone tissue, growth marks are usually apparent, including the closely spaced LAGs of the EFS. However, some specimens do not show growth marks or an EFS in type $\mathrm{F}$ bone tissue.

Type G bone tissue (Fig. 3F) is characterized by an almost complete remodeling of the primary cortex by secondary osteons.

Histologic Ontogenetic Stages in Long Bones.The thirteen HOS stages recognized in sauropod long bones are listed in Table 1. As noted above, there are more HOS stages than ontogenetic bone tissue types (types A-G) because in any one growth series there are specimens that preserve more than one bone tissue type in sequence. Of course, the preservation of successive bone tissue types depends on remodeling and resorption activity because strong resorption will result in a relatively thin cortex and strong remodeling activity will obliterate the primary growth record. This is why the HOS stages that are based on the transition from one bone tissue type to the next are defined such that this transition occurs in the outer cortex, which is least affected by variability in resorption and remodeling.

Ontogenetic Changes in the Histology of Limb Girdle Bones.-Our large sample size (see Appendix) also enabled us to study histological features during ontogeny in limb girdle bones. However, most of these bones grew differently than long bones, mainly with much lower apposition rates, owing to their smaller size or thinner cortex (sauropod scapulae are as large as long bones just thinner). We will describe these histologic changes during ontogeny using the scapula as an example. Scapulae are flat bones, and their sampling location differs from that in long bones. The scapulae were sampled in the anteroposterior middle of the proximal midshaft region (Klein and Sander 2007; see also Curry 1999: Fig. 1). The scapula (Apatosaurus; OMNH 1300, $35.5 \mathrm{~cm}$ ) shows some kind of type $\mathrm{B}$ and type $\mathrm{C}$ tissue in the lateral bone cortex (Fig. 2L). The inner cortex consists of type B bone tissue with loosely arranged, very large round and elliptical vascular canals reminiscent of the longitudinal to radial vascular organization of fibrolamellar bone. Toward the outer cortex, laminar organization increases. However, the whole tissue is very cavernous or primarily cancellous, consisting more of vascular canals than of primary bone. The medial side of OMNH 1300 shows a completely different bone tissue. First, the remodeling zone reaches much farther into the primary cortex, and it has already relatively dense secondary osteons. The remaining primary bone tissue is only a few millimeters thick. The primary bone tissue type is longitudinal fibrolamellar bone, but different from that of long bones or from that of the opposite side. Scapula SMA 0011 (diplodocid; $138.0 \mathrm{~cm}$ ) is almost completely remodeled on the medial side of the bone, whereas the lateral side shows only a few scattered secondary osteons and consists otherwise of longitudinally vascularized primary bone. BYU 725-16614 (Apatosaurus; $127.0 \mathrm{~cm}$ ) has only scattered secondary osteons in the outer cortex of the bone's lateral side. In the exterior cortex and between scattered secondary osteons primary bone is visible, consisting of fibrolamellar bone with a large amount of parallel-fibered bone. The bone tissue in the exterior cortex is lamellar-zonal. 
TABLE 2. Histologic ontogenetic stages (HOS stage), the bone tissue types (A-G), bone dimensions, and body size and mass of Apatosaurus specimens. Percentage adult length of Apatosaurus was estimated from femur/body length ratio (Seebacher 2001; Mazzetta et al. 2004), which is roughly 8\%; the maximum femur length of Apatosaurus in our sample is $180.0 \mathrm{~cm}$. The body mass was calculated after Seebacher (2001). The corresponding body mass for the humeri was based on their corresponding femur length. Specimens were arranged by femur size. $\mathrm{cfl}=$ corresponding femur length. Btt = bone tissue type.

\begin{tabular}{|c|c|c|c|c|c|}
\hline Specimen & Bone length and cfl & HOS & Btt & $\begin{array}{l}\% \text { Adult } \\
\text { length }\end{array}$ & Body mass \\
\hline Tibia OMNH 1285 & $20.05 \mathrm{~cm}(=31.8 \mathrm{~cm} \mathrm{cfl})$ & HOS-4 & type B & 17.6 & $147 \mathrm{~kg}$ \\
\hline Femur OMNH 01279 & $34.0 \mathrm{~cm}$ & HOS-4 & type B & 19 & $179 \mathrm{~kg}$ \\
\hline Humerus OMNH 1278 & $25.8 \mathrm{~cm}(=39.7 \mathrm{~cm} \mathrm{cfl})$ & HOS-4 & type $\mathrm{C}$ & 22 & $291 \mathrm{~kg}$ \\
\hline Femur BYU 601-17103 & $83.0 \mathrm{~cm}$ & HOS-7 & type D & 46 & $2599 \mathrm{~kg}$ \\
\hline Femur BYU 725-17014 & $97.0 \mathrm{~cm}$ & HOS-8 & type $\mathrm{E}$ & 54 & $4168 \mathrm{~kg}$ \\
\hline Humerus CM 21715 & $79.2 \mathrm{~cm}(=121.8 \mathrm{~cm} \mathrm{cfl})$ & HOS-8 & type E & 68 & $8066 \mathrm{~kg}$ \\
\hline Femur BYU 681-11940 & $133.0 \mathrm{~cm}$ & HOS-10 & type $\mathrm{F}$ & 74 & $10,755 \mathrm{~kg}$ \\
\hline Humerus BYU 6812-4749 & $88.0 \mathrm{~cm}(=135.4 \mathrm{~cm} \mathrm{cfl})$ & HOS-8 & type $\mathrm{E}$ & 75 & $10,979 \mathrm{~kg}$ \\
\hline Femur SMA M4/10-1 & $144.0 \mathrm{~cm}$ & HOS-12 & type F & 80 & $13,668 \mathrm{~kg}$ \\
\hline Humerus CM 3378 & $98.0 \mathrm{~cm}(=150.7 \mathrm{~cm} \mathrm{cfl})$ & HOS-11 & type $\mathrm{F}$ & 84 & $15,461 \mathrm{~kg}$ \\
\hline Femur BYU 601-17328 & $158.0 \mathrm{~cm}$ & HOS-12 & type F & 88 & $17,926 \mathrm{~kg}$ \\
\hline Femur SMA Jacques & $164.0 \mathrm{~cm}$ & HOS-10 & type $\mathrm{F}$ & 91 & $20,166 \mathrm{~kg}$ \\
\hline Femur OMNH 01991 & $176.0 \mathrm{~cm}$ & HOS-12 to HOS-13 & type $G$ & 98 & $24,872 \mathrm{~kg}$ \\
\hline Femur OMNH 4020 & $180.0 \mathrm{~cm}$ & HOS-13 & type G & 100 & $26,664 \mathrm{~kg}$ \\
\hline
\end{tabular}

Four LAGs are deposited in this tissue. Only the incompletely drilled medial side of the bone is, as far as preserved, completely remodeled by secondary osteons. Most of the other scapulae (Apatosaurus; BYU 681-16795, $116.0 \mathrm{~cm}$; BYU 681-16782, $125.0 \mathrm{~cm}$; OMNH 01375, $145.5 \mathrm{~cm}$ ) were almost completely remodeled by dense secondary osteons in both cortices.

\section{Histologic Ontogenetic Stage and Body Size}

As first conceptualized by Sander (2000) for the Tendaguru sauropods, the HOS stages in sauropod humeri and femora can be used to construct a growth curve by plotting HOS stages against femur length (as a proxy for body size) (Fig. 4). Bones of very small animals show type $B$ and type $C$ bone tissue (HOS-3 to HOS-6), which represent very fast growth, whereas medium-sized animals show type D and type E bone tissue (HOS-7 to HOS9), in which a successive slow-down in growth rate starts but still a substantial gain in body size was achieved. Large animals usually have type E bone tissue (HOS-10 to HOS-13) where growth significantly decreased or ceased entirely (HOS-10 to HOS-11) and finally plateaued (HOS-12). HOS-13 records the prolonged life of the individual after growth had ceased. This stage corresponds to the "senile" stage of Sander (2000) (Fig. 3, Table 1). At the moment, no time scale for the different ontogenetic stages (HOS stages) is available.

An exemplary interpretation of the Apatosaurus sample is offered in Table 2. In this taxon, HOS-3 occurs in individuals of up to $20 \%$ of adult body length as represented by femur length. HOS-5 occurs in individuals of up to $40 \%$ of adult body length. HOS-7 seems to occur only between $40 \%$ and $50 \%$ of adult body length. HOS-9 occurs in animals of up to $75 \%$ of adult size. HOS-10 to HOS-12, representing type $\mathrm{F}$ bone tissue, is seen in the size class between $75 \%$ and $95 \%$ of adult body length, and HOS-13 only occurs in the largest individuals of Apatosaurus.

Plots of body size versus HOS stage indicate that these stages generally correspond well to body size in sauropods (Fig. 4). This is in contrast to what was observed in the basal sauropodomorph Plateosaurus, which shows developmental plasticity in its bone histology (Sander and Klein 2005; Klein and Sander 2007) as indicated by the lack of correlation between individual age and body size. In Figure 4 , HOS stage (= age) is plotted against the femur length (= body size). For all bones other than the femora, the value of corresponding femur length was used. Apatosaurus, Brachiosaurus, and Diplodocus (Fig. 4A,B,G) show a relatively good relation between HOS stage and femur length. The diplodocine samples 

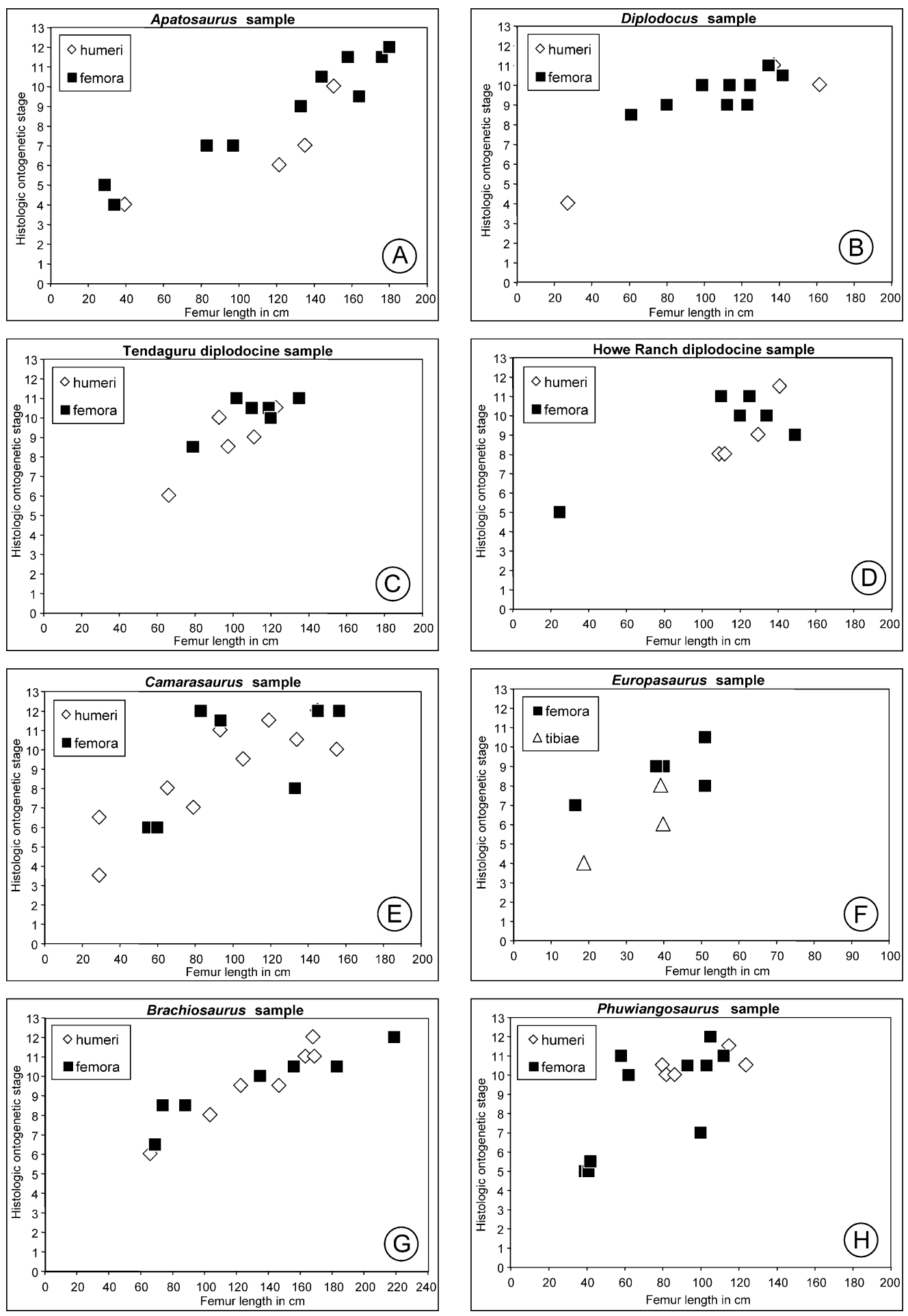

FIGURE 4. Histologic ontogenetic stage (HOS stage) versus femur length in various taxa. A, Apatosaurus. B, Diplodocus. C, Diplodocinae indet. from Howe Ranch locality. D, Diplodocinae indet. from the Tendaguru Beds. E, Camarasaurus. F, Europasaurus. G, Brachiosaurus. H, Phuwiangosaurus. Black rectangles represent femur samples, white diamonds humerus samples, and triangles tibia samples. Humeri and tibiae were calculated to their corresponding femur length. The corresponding femur length for the humeri is based on ratios found in the literature (Janensch 1961; McIntosh 1990; Remes 2006). Although some taxa (Apatosaurus, Brachiosaurus, and Diplodocus) show a very good agreement between body size and HOS stage, others appear more inhomogeneous. See text for discussion. 
from Tendaguru and the Howe Ranch, as well as the Camarasaurus, Europasaurus, and Phuwiangosaurus samples (Fig. 4C-F,H) are less homogeneous for reasons that will be discussed below.

In spite of the very large sample size, constructing a diagram for Ampelosaurus is at the moment not possible because of the fractured or flattened condition of the sampled bones, which makes calculation of the original bone size difficult. From the different diagrams in Figure 4 we conclude that there are some differences among life-history strategies in the sauropods we studied. For example, in the Apatosaurus sample (Fig. 4A) the curve from juveniles (small) to adults (large) is slightly concave, contrary to the Diplodocus and Brachiosaurus sample (Fig. 4B,G), which show a more convex curve. This difference could mean that growth in Apatosaurus juveniles was not as fast as in Diplodocus or Brachiosaurus juveniles. On the other hand, growth in Apatosaurus adults was faster than in Diplodocus adults.

\section{Discussion}

Quality of the Growth Record in Humeri, Femora and Other Bones.-One important result of this study is that the long bones of the sauropods studied (specifically humeri and femora) show a clear correlation between bone size and histologic ontogenetic stage (Table 2, Fig. 4). Nevertheless, these graphs (Fig. 4) also show that there is a small difference between femora and humeri because bone tissue apposition rates are higher in the femora than in the humeri. This was to be expected, at least for taxa with a size discrepancy between humeri and femora such as diplodocid sauropods. For some sauropod taxa, there are no known humeri or femora, raising the question whether other bones might be useful for detecting the ontogenetic status of an individual. Our survey is admittedly incomplete in this regard, having only covered some lower limb bones (ulna, tibia, fibula) and pubis and scapula (the scapula was shown by Curry [1999] to reflect ontogenetic status). Although different ontogenetic stages in bone histology in other bones could be identified, the bone tissue types and the bone apposition rates are, at least in the flat bones (pubis and scapula), different from those observed in the long bones. The comparison of lower limb bones (tibia, fibula, ulna) with humeri and femora is still problematic because of the small sample size for these bones.

Histological Ontogenetic Stages in the Different Sauropod Taxa. - Not all sauropod taxa exhibit all HOS stages in the same manner; i.e. there are taxon-specific differences in bone histology and thus growth trajectory, as already noted by Sander (2000). For example, the young of Ampelosaurus and Phuwiangosaurus already show very well-developed primary osteons in type $\mathrm{B}$ and type $\mathrm{C}$ bone tissue. These primary osteons in Ampelosaurus and Phuwiangosaurus are much more mature than in other sauropods with similar bone tissue types. However, the very young status of these bone tissue types is indicated by other bone histological features (e.g., size, number, and organization of vascular canals) and by the number and form of osteocytes and amount of fibrous and parallel-fibered bone in the fibrolamellar tissue. Ampelosaurus and Phuwiangosaurus show stronger remodeling by dense secondary osteons than do the diplodocids and more basal titanosauromorphs at the same HOS stage. Currently, we cannot explain these differences but they are the focus of more detailed research on titanosaur bone histology (Klein and Sander 2006).

Another difference is the occurrence of growth marks such as lines of arrested growth (LAGs). In Diplodocidae, Brachiosaurus, and Camarasaurus, growth marks are more frequent than in Ampelosaurus and Phuwiangosaurus. In Europasaurus growth marks occur regularly (Sander et al. 2006). In the other taxa, sample size is too small to evaluate this feature. Although in sauropods it is generally unclear what events late in the life history of the animal triggered the deposition of LAGs, within several taxa some presumable adults show growth marks but not others. Because of the large sample size and the size spectrum of the studied specimens (Appendix), a sampling artifact seems unlikely, and a biological cause (endogenous or exogenous factors) is hypothesized.

HOS-13 (complete remodeling by secondary osteons) is seen only in the femora and humeri 
of Apatosaurus, Ampelosaurus, and some specimens of Camarasaurus (type 1). This may be because the largest individuals of the other taxa are poorly represented in the fossil record. Thus, the recorded growth history as represented by this histologic stage is simply not preserved in the other taxa. There is no evidence that the pattern of secondary osteon development is dependent on body mass because Brachiosaurus as the heaviest taxon sampled shows less remodeling than Apatosaurus or the medium-sized Ampelosaurus. As noted earlier, the issue of the controls on secondary remodeling is beyond the scope of this paper and will not be discussed further. Another difference between Apatosaurus and some other taxa is that adult bone tissue type I is not as well developed in this taxon, suggesting that HOS-9 in Apatosaurus, seen only in a few specimens, did not last very long. All these differences in growth trajectories are of particular interest when viewed in an evolutionary context.

In addition to the variation seen among different taxa, it is obvious from the graphs in Figure 4 that there is also variation within taxa, more properly within the operational taxonomic units (OTUs) used in this study. The Howe Ranch Diplodocinae sample, the Camarasaurus sample, and the Phuwiangosaurus sample did not show a good correlation between femur length and HOS stage (Fig. 4D,E,H). There are several explanations for this variability that are not mutually exclusive: (1) Errors in histologic stage assignment; (2) true individual variation as seen in any biological species; (3) sexual dimorphism in growth trajectories; and (4) cryptic biological species that differ in histology and growth trajectory but cannot be separated morphologically, at least in the known skeletal parts. Whereas explanations 1 and 2 certainly play a role but are difficult to assess, explanations 3 and 4 deserve further comment.

The current study did not find support for explanation 3, sexually differentiated growth trajectories, in any of the OTUs. Although Sander (2000) interpreted the data for the Tendaguru diplodocine under the premise that this material represents a single biological species, the work of Remes (2006) indicates that at least two diplodocine species are represented by the material listed as Barosaurus

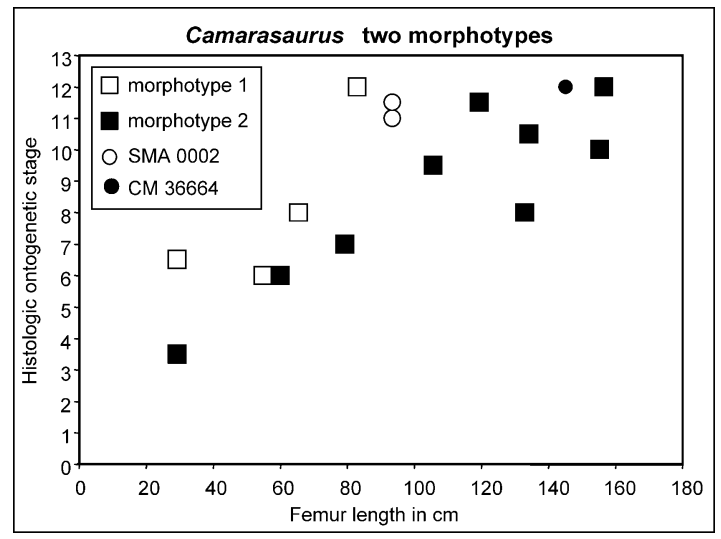

FIGURE 5. HOS stages versus femur length in Camarasaurus are interpreted in this graph as reflecting two morphotypes. Individual SMA 0002 (humerus $70.5 \mathrm{~cm}$, femur $93.5 \mathrm{~cm}$ ) thus would represent morphotype 1 and individual CM 36664 (humerus $117.2 \mathrm{~cm}$, femur 145.2 $\mathrm{cm})$, morphotype 2 .

africanus by Janensch (1961). It now appears likely that Sander's histotypes A and B of "Barosaurus africanus" represent two different species: type A is Tornieria africana (Remes 2006) and type B could be Australodocus, another diplodocine from the Tendaguru Beds (Remes 2007).

The material ascribed to the genus Camarasaurus may represent an example of explanation 4 as suggested by Figure 5. The bone histology shows clearly that some individuals in this sample are older at a generally smaller body size. Although explanation 3 might be worth considering as well, this would mean a size difference of nearly $50 \%$ between the sexes. Phuwiangosaurus (Fig. 4H) and Ampelosaurus (not shown) also exhibit an inhomogeneous pattern of size (femur length) plotted versus HOS stage samples despite the large sample size for these OTUs. However, the material derives in both cases from several localities spread over a relatively extensive geographic area. In addition, the calculation of bone length is problematic for Ampelosaurus because some bones are badly compressed.

Comparison with Other Studies on Histologic Ontogenetic Stages.-Erickson and Tumanova (2000) erected a similar system for a sample of the ceratopsian Psittacosaurus monogoliensis, assigning the number of LAGs (= estimated age in years) in a given femur size to a growth stage system, running from growth stage A to growth 
stage G. However, although they did not discuss biological meaning of each of these stages, they did find that these stages represented growth series from juvenile through adult (Erickson and Tumanova (2000).

The HOS stages described by Horner et al. (2000) for the hadrosaur Maiasaura are comparable with our observations in their general pattern. These authors describe rather fast growth in the young animals (nestling, juvenile, subadult). Growth slows down in adults, and the animals finally reach a growth plateau. The differences between their study and ours in details of bone histology and in the interpretation and nomenclature of the described bone tissue types $(A-G)$ are related to the different taxa (hadrosaur versus sauropod) and life histories (altricial young in Maiasaura versus presumably precocial young in sauropods [Carpenter 1999; Sander et al. in press]).

The study of an ontogenetic series of Apatosaurus bones by Curry (1999) is difficult to compare with our HOS stages because Curry did not study the same long bones (humerus and femur). However, the bone tissue types in the radii and ulnae that she studied (Curry 1999: Fig. 2) are similar to our type $C$ and type $\mathrm{D}$ bone tissue in the humeri and femora of sauropods (HOS-5 to HOS-7), although the radii and ulnae (Curry 1999: Fig. 2) already show a number of scattered secondary osteons. Thus in comparison to our results, her age estimates of "early juvenile" for these lower limb bones of Apatosaurus are too young and, on the other hand, her percentages of adult body sizes for Apatosaurus early ontogenetic stages are too high; e.g., the early juveniles are $61 \%$ of adult size (Curry 1999: Table 1). The scapula (117.4 $\mathrm{cm}$ long) from the Cactus Park locality that she sampled is the same bone as our sampled specimen BYU 681-16795 $(116.0 \mathrm{~cm})$. Curry's evaluation of bone tissue type (late juvenile) (1999: Fig. 5A) is similar to our evaluation (type $\mathrm{D}$ bone tissue = subadult to type $\mathrm{E}$ bone tissue $=$ adult I), keeping in mind that we sampled both the median and lateral sides of the bone, which results in some additional information to Curry's sample. However, we do not agree with her extrapolated adult body size of this bone (Curry 1999: Table 1; 56\% of adult size), because of a different calculation method. According to our extrapolation method this scapula has a corresponding size of $\sim 70 \%$ of maximal adult body size.

Sander (2000) and Sander and Tückmantel (2003) studied the transition from type D bone tissue (subadult) to type E bone tissue (adult bone) in sauropods in some detail. Note, however, that they did not distinguish a type $\mathrm{D}$ bone tissue but called both the current type $C$ bone tissue and type D bone tissue "juvenile bone." Sander (2000) was able to quantify the drop in vascularity from our type $\mathrm{D}$ bone tissue to type E bone tissue, and Sander and Tückmantel (2003) showed that the decrease in vascularization was not because of a decrease in initial vascular canal size but to an increase in infilling of the vascular canals, because lamina thickness was rather uniform in both type D and type $\mathrm{E}$ bone tissue, and also uniform across different specimens and taxa of sauropods.

Biologic Ontogenetic Stages.-Terms such as embryo, hatchling, juvenile, subadult, and adult, which originate from the study of life history in recent amniotes, are also in common use for extinct taxa. However, these terms are usually used in a morphological and size-related context. Their definition and their ontogenetic meaning for living animals vary from group to group, mainly depending on the specific life histories. The use of these terms for extinct species is problematic and only hypothetical. However, the bone tissue types described here (types A$\mathrm{G})$ are hypothesized to correspond to biologic ontogenetic stages: Bone tissue type A may correspond to the bone tissue of an embryo; type $B$ to that of a hatchling; type $C$ to that of a juvenile; type $\mathrm{D}$ to that of a subadult; type $\mathrm{E}$ to that of a young, still growing adult; type $\mathrm{F}$ to that of an adult, where growth had stopped (development of an EFS); and finally type G, the completely remodeled bone tissue of a senescent individual.

Determination of Sexual Maturity from the Ontogenetic Histologic Stages.-Determining sexual maturity in extinct animals is rather controversial (Curry 1999; Sander 2000; Horner et al. 2000; Chinsamy-Turan 2005; Erickson 2005; Erickson et al. 2007; Klein and Sander 2007) and remains hypothetical until clear evidence, such as medullary bone, is discovered for a taxon. Medullary bone is known from re- 
cent ovulating birds (Chinsamy-Turan 2005) and also from the theropod Tyrannosaurus (Schweitzer et al. 2005), in which it clearly indicates a sexually mature female. However, in our large sauropodomorph sample (Appendix; see also Klein and Sander 2007), no medullary bone is preserved.

Sander (2000) hypothesized that sexual maturity in sauropods is recorded in HOS stages, but this has not met with universal agreement (e.g., Erickson 2005; Chinsamy-Turan 2005). Although sexual maturity has not been identified with certainty in the bone histology of extinct vertebrates, one can argue the pro and cons for several possible moments in an individual's histological growth record as indicators of the onset of sexual maturity. Sander's (2000) reasoning was that the attainment of sexual maturity resulted in a decrease in growth rate due to the shift in resources from growth to reproduction as a sauropod became sexually mature. This is the pattern seen in virtually all living tetrapods and presumably applied to sauropods as well. As the current study shows, bone histology in sauropods documents several decreases in linear growth rate (Fig. 3), and the question arises which of them might reflect sexual maturity.

One possibility, favored by Curry (1999), is that sexual maturity coincided with attainment of final size, as reflected by the deposition of an EFS or a similar bone tissue type (HOS-12 in the current study). This possibility can be evaluated by using the limited quantitative life-history data available for sauropods. Using growth cycles, Sander (2000) estimated that an individual of the basal titanosaur $\mathrm{Ja}$ nenschia required at least 26 years to reach final size. However, an individual of Apatosaurus of 91\% maximum size (SMA 0014; Table 2) shows 25 growth cycles in the outer cortex (Sander and Tückmantel 2003), suggesting that it was at least 30 years old. In this case sexual maturity would not be attained until the end of the third decade of life, which was considered highly unlikely by Dunham et al. (1989) for any dinosaur. HOS-12 thus can probably be excluded from consideration for recording sexual maturity.

Earlier possible stages are HOS-10 and HOS8. Arguing against HOS-10 is again the rather large size and thus old age of the animals involved. This is why we favor HOS-8 to HOS-9. As Erickson et al. (2007) and Lee and Werning (2008) recently showed, in non-avian theropod and ornithischian dinosaurs sexual maturity also occurred well before full adult size was reached. Our Apatosaurus sample (Table 2) suggests a body size of $\sim 50 \%$ maximum adult size at HOS-8. This would correspond to a femur length of $90.0 \mathrm{~cm}$ or $11.25 \mathrm{~m}$ body length. Attainment of sexual maturity at about one-half maximum body size is consistent with the life histories of modern large reptiles such as crocodiles and turtles but not with those of large herbivorous mammals.

\section{Conclusions}

This study shows that well-constrained core samples of the large long bones of sauropod dinosaurs can be used to identify seven defined bone tissue types (A-G) that correspond to the ontogenetic status of a given sauropod individual with great accuracy, assigning it to one of the 13 HOS stages designated herein. We were able to designate so many HOS stages because of our large sample size and the uniform growth of sauropod long bones. Although variations of HOS stages do occur among different neosauropod taxa, these are mainly related to the relative importance of the stages in their ontogeny. We thus feel that these stages can be applied to other neosauropods, and their utility can be tested by other workers. In fact, we hope that it will become accepted practice in the study of sauropods and other dinosaurs that any description of a new taxon will be accompanied by determination of its ontogenetic status using bone histology. This would help avoid much controversy surrounding specimens that are rather similar morphologically but differ greatly in body size.

In all sauropod taxa studied, there is a close correlation between body size and ontogenetic stage, suggesting that sauropods had lost developmental plasticity and grew along a genetically predetermined growth trajectory. However, although sauropods appear to show a more reptilian growth curve in probably having had an early onset of sexual maturity, as was also shown recently for some other dinosaurs (Erickson et al. 2007; Lee and Werning 
2008), their growth rates must have been as high as in birds or mammals.

In the virtual absence of cyclical growth marks in sauropod long bones, we believe HOS stages are a considerable improvement over a purely qualitative analysis of the growth record. Nevertheless, we would like to obtain fully quantitative sauropod growth curves in which size and body mass gain are plotted as a function of time. This could be achieved if specific growth rates could be derived for the different bone tissue types (i.e., juvenile, subadult, and adult bone) by measuring them in recent equivalents of these tissues or deriving them from other fossil specimens that show these tissues to be interrupted by growth marks such as bones of the sauropod skeleton growing with negative allometry.

Comparison of growth trajectories of sister groups reveals evolutionary change by heterochrony. Because our work produces growth trajectories of a wide variety of sauropod taxa, it provides the foundation for a much refined understanding of body-size evolution in sauropods. We have shown this already for the evolution of dwarfing in the basal macronarian Europasaurus (Sander et al. 2006) and the evolution of the first giant sauropods from much smaller prosauropod ancestors (Sander et al. 2004).

\section{Acknowledgments}

In a study based on destructive methods, the open minds and help of curators are of utmost importance. It therefore is our particular pleasure to acknowledge the following individuals for giving permission for and aid in sampling specimens in their care: D. Berman (CM), E. Buffetaut (LMC), R. Cifelli and K. Davies $(\mathrm{OMNH})$, W.-D. Heinrich (MfN), N. Knötschke (DFMMh/FV), J. Le Loeuff (MDE), H.P. Schultze (MfN), K. Stadtman (BYU), H. H. J. Siber (SMA), and V. Suteethorn (PC.DMR). R. Wilhite (Louisiana State University, Baton Rouge) is acknowledged for providing identifications and measurements of sauropod long bones in the BYU collections. We also would like to thank O. Dülfer and G. Oleschinski (both Institute of Paleontology, University of Bonn), who did a great job in cutting the thin sections and photographing them for study. The manuscript has greatly benefited from reviews by G. Erickson and an anonymous reviewer. Our research was funded by the Deutsche Forschungsgemeinschaft (DFG) through grants SA $469 / 7$ and SA $469 / 16$. This is contribution number 40 of the DFG Research Unit 533, "Biology of the Sauropod Dinosaurs."

\section{Literature Cited}

Amprino, R. 1947. La structure du tissue osseux envisagée comme expression de differences dans la vitesse de 1'accroissement. Archives de Biologie 58:315-330.

Ayer, J. 2000. The Howe Ranch dinosaurs. Sauriermuseum Aathal, Zürich.

Bonnan, M. F. 2004. Morphometric analysis of humerus and femur shape in Morrison sauropods: implications for functional morphology and paleobiology. Paleobiology 30:444-470.

Carpenter, K. 1999. Eggs, nests, and baby dinosaurs: a look at dinosaur reproduction. Indiana University Press, Bloomington.

Carpenter, K., and J. McIntosh. 1994. Upper Jurassic sauropod babies from the Morrison Formation. Pp. 372 in K. Carpenter, K. Hirsch, and J. Horner, eds. Dinosaur eggs and babies. Cambridge University Press, Cambridge.

Chiappe, L. M., and S. L. Coria. 2001. Embryonic skulls of titanosaur sauropod dinosaurs. Science 293:2444-2446.

Chiappe, L. M., F. Jackson., R. A. Coria, and L. Dingus. 2005. Nesting titanosaurs from Auca Mahuevo and adjacent sites: understanding sauropod reproductive behaviour and embryonic development. Pp. 285-302 in K. Curry Rogers and J. A. Wilson, eds. The sauropods: evolution and paleobiology. University of California Press, Berkeley.

Chinsamy, A. 1993. Bone histology and growth trajectory of the prosauropod dinosaur Massospondylus carinatus (Owen). Modern Geology 18:319-329.

- 1994. Dinosaur bone histology: implications and inferences. Pp. 213-227 in G. D. Rosenberg and D. L. Wolberg, eds. DinoFest. Paleontological Society Special Publication 7:213-227.

Chinsamy-Turan, A. 2005. The microstructure of dinosaur bone. Johns Hopkins University Press, Baltimore.

Cormack, D. 1987. Ham's histology. Lippincott, New York.

Currey, J. D. 2002. Bones: structure and mechanics. Princeton University Press, Princeton, N.J.

Curry, K. 1999. Ontogenetic histology of Apatosaurus (Dinosauria: Sauropoda): new insights on growth rates and longevity. Journal of Vertebrate Paleontology 19:654-665.

Dunham, A. E., K. L. Overall, W. P. Porter, and C. A. Forster. 1989. Implications of ecological energetics and biophysical and developmental constraints for life-history variation in dinosaurs. In J. O. Farlow, ed. Paleobiology of the dinosaurs. Geological Society of America Special Paper 238:1-21.

Erickson, G. M. 2005. Assessing dinosaur growth patterns: a microscopic revolution. Trends in Ecology and Evolution 20: $677-684$.

Erickson, G. M., and T. A. Tumanova. 2000. Growth curve of Psittacosaurus mongoliensis Osborn (Ceratopsia: Psittacosauridae) inferred from long bone histology. Zoological Journal of the Linnean Society 130:551-566.

Erickson, G. M., P. J. Currie, B. D. Inouye, and A. A. Winn. 2006. Tyrannosaur life tables: an example of nonavian dinosaur population biology. Science 313:213-217.

Erickson, G. M., K. Curry-Rogers, D. J. Varricchio, M. A. Norell, and X. Xu. 2007. Growth pattern in brooding dinosaurs re- 
veals the timing of sexual maturity in non-avian dinosaurs and genesis of the avian condition. Biology Letters 3:558-561.

Foster, J. R. 2005. New juvenile sauropod material from Western Colorado, and the record of juvenile sauropods from the Upper Jurassic Morrison Formation. Pp. 141-153 in Tidwell and Carpenter 2005.

Francillon-Vieillot, H., V. de Buffrenil, J. Castanet, J. Geraudie, F. J. Meunier, J. Y. Sire, L. Zylenberberg, and A. de Ricqlès. 1990. Microstructure and mineralization of vertebrate skeleta tissues. Pp. 471-530 in J. E. Carter, ed. Skeletal biomineralization: patterns, processes and evolutionary trends. Van Nostrand Reinhold, New York.

Gilmore, C. W. 1925. A nearly complete articulated skeleton of Camarasaurus, a saurischian from the Dinosaur National Monument, Utah. Memoirs of the Carnegie Museum 10:347-384.

Horner, J. R., and K. Padian. 2004. Age and growth dynamics of Tyrannosaurus rex. Proceedings of the Royal Society of London B 27:1875-1880.

Horner, J. R., A. de Ricqlès, and K. Padian. 2000. Long bone histology of the hadrosaurid dinosaur Maiasaura peeblesorum: growth dynamics and physiology based on an ontogenetic series of skeletal elements. Journal of Vertebrate Paleontology 20:115-129.

Horner, J. R., K. Padian, and A. de Ricqlès. 2001. Comparative osteohistology of some embryonic and perinatal archosaurs developmental and behavioral implications for dinosaurs. Paleobiology 27:39-58.

Ikejiri, T., V. Tidwell, and D. Trexler. 2005. New adult specimens of Camarasaurus lentus highlight ontogenetic variation within the species. Pp. 154-179 in Tidwell and Carpenter 2005.

Janensch, W. 1961. Die Gliedmaßen und Gliedmaßengürtel der Sauropoden der Tendaguru-Schichten. Palaeontographica 3(Suppl. 7):177-235.

Jianu, C. M., and D. B. Weishampel. 1999. The smallest of the largest: a new look at possible dwarfing in sauropod dinosaurs. Geologie en Mijnbouw 78:335-343.

Klein, N., and P. M. Sander. 2006. An unusual bone histology and growth pattern in Ampelosaurus atacis, a titanosaurid sauropod from South France. Journal of Vertebrate Paleontology 26(Suppl. to No. 3):85A

2007. Bone histology and growth of the prosauropod dinosaur Plateosaurus engelhardti (von Meyer 1837) from the Norian bonebeds of Trossingen (Germany) and Frick (Switzerland). Special Papers in Palaeontology 77:169-206.

Lee, A., and S. Werning. 2008. Sexual maturity in growing dinodaurs does not fit reptilian growth models. Proceedings of the National Academy of Sciences USA 105:582-587.

Lehmann, T. M., and A. B. Coulson. 2002. A juvenile specimen of the sauropod dinosaur Alamosaurus sanjuanensis from the Upper Cretaceous of Big Bend National Park, Texas. Journal of Paleontology 76:156-172.

Le Loeuff, J. 2005a. Osteology of Ampelosaurus atacis (Titanosauria) from Southern France. Pp.115-137 in Tidwell and Carpenter 2005 .

. 2005b. Romanian Late Cretaceous dinosaurs: big dwarfs or small giants? Historical Biology 17:15-17.

Martin, V. 1994. Baby sauropods from the Sao Khua Formation (Lower Cretaceous) in Northeastern Thailand. Gaia 10:147-153.

Mazzetta, G. V., P. Christiansen, and R. A. Farin. 2004. Giants and bizarres: body size of some southern South American Cretaceous dinosaurs. Historical Biology 2004:1-13.

McIntosh, J. 1990. Species determination in sauropod dinosaurs with tentative suggestions for their classification. Pp. 53-69 in K. Carpenter and P. Currie, eds. Dinosaur systematics: per- spectives and approaches. Cambridge University Press, Cambridge.

Reisz, R. R., D. Scott, H.-D. Sues, D. C. Evans, and M. A. Raath. 2005. Embryos of an Early Jurassic prosauropod dinosaur and their evolutionary significance. Science 309:761-764.

Remes, K. 2006. Revision of the Tendaguru sauropod dinosaur Tornieria africana Fraas and its relevance for sauropod paleobiogeography. Journal of Vertebrate Paleontology 26:651-669.

- 2007. A second Gondwana diplodocid dinosaur from the Upper Jurassic Tendaguru Beds of Tanzania, East Africa. Palaeontology 50:653-667.

Sander, P. M. 1999. Life history of Tendaguru sauropods as inferred from long bone histology. Mitteilungen Museum für Naturkunde Berlin, Geowissenschaftliche Reihe 2:103-112.

- 2000. Longbone histology of the Tendaguru sauropods: implications for growth and biology. Paleobiology 26:466-488.

Sander, P. M., and N. Klein. 2005. Unexpected developmental plasticity in the life history of an early dinosaur. Science 310: 1800-1802.

Sander, P. M., and C. Tückmantel. 2003. Bone lamina thickness, bone apposition rates, and age estimates in sauropod humeri and femora. Paläontologische Zeitschrift 77:161-172.

Sander, P. M., N. Klein, E. Buffetaut, G. Cuny, V. Suteethorn, J. Le Loeuff. 2004. Adaptive radiation in sauropod dinosaurs: bone histology indicates rapid evolution of giant body size through acceleration. Organisms, Diversity, and Evolution 4: 165-173.

Sander, P. M., O. Mateus, T. Laven, and N. Knötschke. 2006. Bone histology indicates insular dwarfism in a new Late Jurassic sauropod dinosaur. Nature 441:739-741.

Sander, P. M., F. Jackson, and L. M. Chiappe. In press. Upper Cretaceous titanosaur nesting sites and their implications for sauropod dinosaur reproductive biology. Palaeontographica, Abteilung A.

Schwarz, D., T. Ikejiri, B. H. Breithaupt, P. M. Sander, and N. Klein. 2007. A nearly complete skeleton of an early juvenile diplodocid (Dinosauria: Sauropoda) from the Lower Morrison Formation (Late Jurassic) of North Central Wyoming and its implications for early ontogeny and pneumaticity in sauropods. Historical Biology 19:225-253.

Schweitzer, M. H., J. L. Wittmeyer, and J. R. Horner. 2005. Gender-specific reproductive tissue in ratites and Tyrannosaurus rex. Nature 308:1456-1460.

Seebacher, F. 2001. A new method to calculate allometric lengthmass relationships of dinosaurs. Journal of Vertebrate Paleontology 21:51-60.

Tidwell, V., and K. Carpenter, eds. 2005. Thunder-lizards. Indiana University Press, Bloomington.

Tidwell, V., and R. Wilhite. 2005. Ontogenetic variation and isometric growth in the forelimb of the Early Cretaceous sauropod Venenosaurus. Pp. 187-196 in Tidwell and Carpenter 2005.

Varricchio, D. J. 1993. Bone microstructure of the Upper Cretaceous theropod dinosaur Troodon formosus. Journal of Vertebrate Paleontology 13:99-104.

Wilhite, R. 2003. Biomechanical reconstruction of the appendicular skeleton in three North American Jurassic sauropods. $\mathrm{Ph} . \mathrm{D}$. dissertation. Louisiana State University, Baton Rouge.

Wilson, J. A. 2002. Sauropod dinosaur phylogeny: critique and cladistic analysis. Zoological Journal of the Linnean Society of London 136:217-276.

Xu, X., Q. Tan, J. Wang, X. Zhao and L. Tan. 2007. A gigantic bird-like dinosaur from the Late Cretaceous of China. Nature 447:884-847. 